\title{
The case guidance system in China: a practical guide to intellectual property cases
}

Citation for published version (APA):

Lu, T. (2021). The case guidance system in China: a practical guide to intellectual property cases. Journal of Intellectual Property Law \& Practice, 16(3), 207-212. https://doi.org/10.1093/jiplp/jpab058

Document status and date:

Published: 01/03/2021

DOI:

10.1093/jiplp/jpab058

Document Version:

Publisher's PDF, also known as Version of record

Document license:

Taverne

Please check the document version of this publication:

- A submitted manuscript is the version of the article upon submission and before peer-review. There can be important differences between the submitted version and the official published version of record.

People interested in the research are advised to contact the author for the final version of the publication, or visit the DOI to the publisher's website.

- The final author version and the galley proof are versions of the publication after peer review.

- The final published version features the final layout of the paper including the volume, issue and page numbers.

Link to publication

\footnotetext{
General rights rights.

- You may freely distribute the URL identifying the publication in the public portal. please follow below link for the End User Agreement:

www.umlib.nl/taverne-license

Take down policy

If you believe that this document breaches copyright please contact us at:

repository@maastrichtuniversity.nl

providing details and we will investigate your claim.
}

Copyright and moral rights for the publications made accessible in the public portal are retained by the authors and/or other copyright owners and it is a condition of accessing publications that users recognise and abide by the legal requirements associated with these

- Users may download and print one copy of any publication from the public portal for the purpose of private study or research.

- You may not further distribute the material or use it for any profit-making activity or commercial gain

If the publication is distributed under the terms of Article $25 \mathrm{fa}$ of the Dutch Copyright Act, indicated by the "Taverne" license above, 


\title{
Practice Point
}

\section{The case guidance system in China: a practical guide to intellectual property cases}

\author{
Tian Lu*
}

In 2005, the Supreme People's Court of China (SPC) issued the Second Five-Year Reform Outline for the People's Courts (2004-2008), ${ }^{1}$ officially introducing the concepts of the case guidance system (CGS) and guiding cases (指导性案例, GCs) and designating their construction as crucial for China's judicial reform. In 2014, an aim 'to strengthen and regulate case guidance' was promoted to become a policy of the Chinese Communist Party. ${ }^{2}$

The CGS' main body features an overall ' $1+\mathrm{x}$ ' structure, such that the SPC's GCs are at the top and all other types of example cases lie beneath. ${ }^{3}$ GCs have quasi-legal source status, whereas none of the remaining cases are sources of law.

\section{The SPC's GCs}

The system of the SPC's GCs was established when two judicial interpretation documents-The Provisions on Case Guidance ('the 2010 Provisions') ${ }^{4}$ and The Detailed Rules for the Implementation of the Provisions of the Supreme People's Court on Case Guidance ('the Detailed Rules 2015') ${ }^{5}$ — were issued by the SPC in 2010 and 2015, respectively. This system's goal was to summarize trial experiences, unify the law's application, enhance trial quality and maintain judicial justice. $^{6}$

As officially defined, 'GC' is a notion that refers to the cases 'whose judgements have come into force and satisfy the following conditions: (1) attract wide attention from society; (2) the legal provisions are, to a greater degree, on the principles of law; (3) representative; (4) challenging, complicated or novel; or (5) other cases that have a guiding function. ${ }^{, 7}$

\section{Email: tian.ipkat@gmail.com}

1 Notice of the Supreme People's Court on Issuing the Second Five-Year Reform Outline for the People's Courts (2004-2008), Fafa [2005] No 18, effective from 26 October 2005.

2 By the Decision of the Central Committee of the Communist Party of China on Major Issues Pertaining to Comprehensively Promoting the Rule of Law issued at the Fourth Plenary Session of the 18th Central Committee of the Communist Party of China on 23 October 2014.

3 The People's Procuratorate's GCs are beyond the scope of this article.

\section{The author}

- Tian $\mathrm{Lu}$ is a PhD candidate in intellectual property law at Maastricht University.

\section{This article}

- According to the country's Constitution, the People's Republic of China features a 'socialist legal system' in which statutory law, rather than case law, is the primary source of law. However, that does not reduce the value of the attention China has directed to establishing the case guidance system (CGS). Although the CGS is not used according to case law, it provides a useful observation window.

- The CGS is intricate and contains multiple subsets of example cases, which are selected by various bodies and announced in various styles. These subsets often bear similar names (eg guiding cases, model cases and referential cases), yet they may produce different outcomes.

- The CGS is not a plain collection of cases per se. Each subset of the CGS is often accompanied by the issuing bodies' summaries and comments on the cases, which highlight specific guiding points thereof.

- This article provides, from a practical perspective, a layered introduction to the main courtissued CGS example cases that can be easily accessed online, with a specific focus on intellectual property cases. Guidance, Fafa [2010] No 51, effective from 26 November 2010.

5 Detailed Rules for the Implementation of the Provisions of the Supreme People's Court on Case Guidance, Fafa [2015] No 130, effective from 13 May 2015.

6 See the opening section of the Provisions 2010. The translation of laws in this article is by the PKU Law, a leading databased since 1985.

7 The Provisions 2010 (n 4) art 2. 
GCs are selected and released through strict statutory procedures. The SPC is the only competent authority that determines and uniformly publishes GCs, ${ }^{8}$ and it does so by directly making its own decisions or selecting cases recommended by the higher people's courts. ${ }^{9}$ The intermediate and grassroots people's courts can also recommend candidate cases; those recommendations must first be decided through deliberation by the court's judicial committee and then reported to the higher people's courts level by level. ${ }^{10}$ This process appears to be conducted with administrative intensity.

GCs carry considerable referential weight, which is mainly established in Article 7 of the 2010 Provisions as follows:

When trying similar cases, people's courts at all levels shall use the guiding cases issued by the Supreme People's Court as a reference.

The seemingly contradictory wording of 'shall' and 'use as a reference' accurately indicate the uniqueness of GCs. The word 'shall' confirms that the de facto institutional authority of the SPC equips GCs with an unprecedented normative binding force compared with the other example cases. Furthermore, the wording 'use as a reference' reveals that the normative binding force is relatively weaker than actual sources of law are in China, such as statute laws and judicial interpretations. ${ }^{11}$

Furthermore, the wording 'shall' should not be understood in an overly general manner because GCs can vary in contents. For example, GCs might be cases that were ruled through the direct citation of explicit legal provisions or the citation of cases in which interpretations or elaborations are provided within the context of the law. After all, the National People's Congress and its Standing Committee possess the State's legislative power. ${ }^{12}$ In contrast, the SPC can merely provide interpretations of the law's specific application within trial work. ${ }^{13}$ The guidance provided by GCs either overlaps with the rigidly defined coverage of laws or extends to the areas further yet still within the range of the original text of statutes. However, the logical order still begins with statutory law rather than with GCs.

\footnotetext{
8 ibid art 1

9 ibid art 4(1)(2).

10 ibid art 4(3).

11 Lei Lei, 'Rethinking the Status of the Source of Law of Guiding Cases' (2015) 1 China Legal Science 272-90.

12 In art 7 of the Legislation Law of the People's Republic of China (2015 Amendment), adopted by the Third Session of the Ninth National People's Congress on 15 March 2000, Order No 20 of the President, effective from 15 March 2015.

13 ibid art 104
}

Although GCs are not a binding source of law in China and are thus ineligible for citation as the basis of judgment, they are explicitly allowed to be cited in the reasoning of courts. ${ }^{14}$

From a practical perspective, despite the pivotal position of GCs in the CGS and their merits, the quantity of GCs is small. From the first publication of a GC in January 2012 to the end of 2020, a mere 143 GCs were published in total, including fewer than 30 intellectual property (IP)-related GCs (IPGCs). Compared with the large number of IP cases heard annually in China, this number is almost insignificant. The apparent rarity of IPGCs considerably limits the coverage of these applications in practice.

\section{Other cases}

The ' $\mathrm{x}$ ' in the overall $1+\mathrm{x}$ structure of the CGS encompasses a wide range of example cases of various styles and names. None of them are a source of law in China.

Although some of the case announcements in this 'category $\mathrm{x}$ ' have a provided structure or style of guidance which may resemble that of judicial interpretations, these case announcements are fundamentally different from judicial interpretations. Judicial interpretations are legally binding on the lower courts and follow strict statutory procedures and formats (eg by having an official Interpretation Number). ${ }^{15}$

This section highlights the prominent IP cases in this 'category $\mathrm{x}$ ' that can be easily accessed online.

\section{A. The SPC gazette cases}

In the 1950s, the SPC began using cases to guide lower courts' trial activities. ${ }^{16}$ Since 1985, the SPC Gazette has been a reliable source that reports many key legal documents and cases.

The regularly published SPC Gazette has several fixed columns, including 'Judicial Interpretations', 'Personnel Appointment' and 'Cases'. In 2003, a new column, 'Publication of Selected Judgement', was added. Since the second issue of the SPC Gazette was published in 2004, a 'Judicial Abstract' section, which conveys

14 art 10 of the Detailed Rules 2015. Several judgments contain the citation of GCs in the reasoning part, eg, No 5 [2021], Enforcement Reconsideration, 01, Liaoning and No 40 [2021], Objection to Enforcement, 1402, Shandong.

15 art 5 of the Notice by Supreme People's Court on Issuing the Provisions of the Supreme People's Court on the Judicial Interpretation Work, Fafa [2007] No 12, effective from 1 April 2007.

16 See <http:// www. court. gov. cn/ zixun- xiangqing- 13007. html> accessed 15 March 2021. 


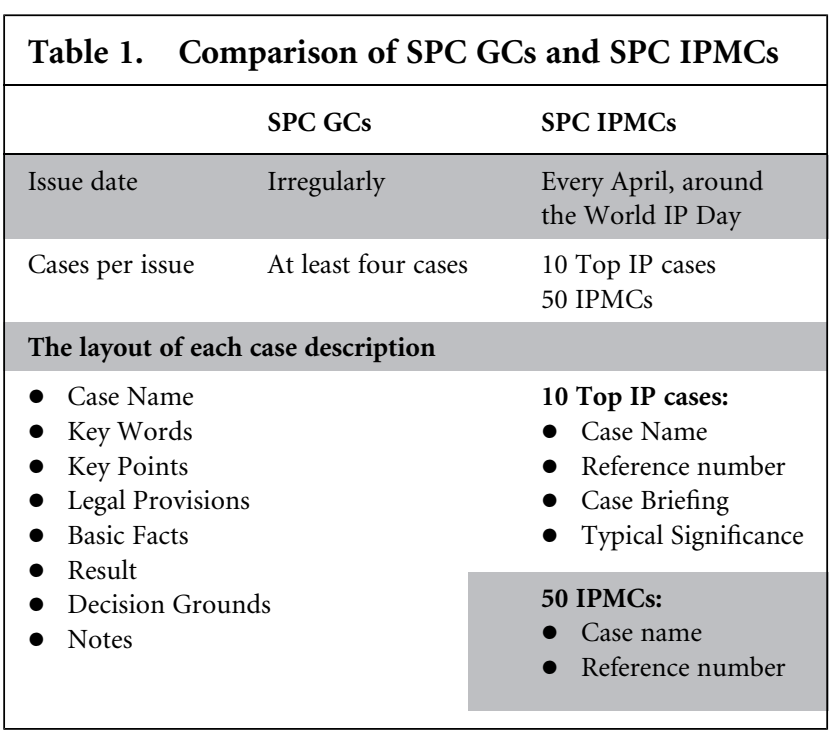

specific points that the SPC intends to stress, has been added to each case published in the 'Cases' and 'Publication of Selected Judgement' columns. The SPC Gazette also reports on IP cases.

\section{B. SPC ' $10+50$ ' IP-related model cases}

Unlike the proper noun 'GC', 'model case' (典型案例, ' $M C$ ') is an umbrella term that can refer to various cases selected by different bodies. Notably, the SPC has regularly issued two types of IP-related MCs (IPMCs) since 2009: the top 10 IP cases and the 50 (annual) IPMCs. ${ }^{17}$ A basic comparison of the two MCs with GCs is provided in Table 1:

Notably, GCs contain the SPC's abundant guidance opinions. After selection, some 'ordinary' judgments in force are 'upgraded' to GC status, with the SPC's summaries or comments inserted; such insertion occurs mainly in the 'Key Points of Adjudication' section of the SPC Gazette. This section presents the results after the SPC's weighing and comparing multiple elements involved in each case.

For example, consider GC no 114, which was the Dior 3D trade mark case. Of the two major issues in dispute-one issue procedural and the other substantive- the SPC considered the procedural issue to be key to the case. ${ }^{18}$

17 Since 2007, the SPC started to release the annual 'Top Ten Cases of IP Judicial Protection', which was renamed as the 'Top Ten IP Cases' in 2013. Since 2009, the SPC began to announce the '50 IPMCs' together with the 'Top Ten Cases of IP Judicial Protection'.

18 Parfumes Christian Dior v Trade Mark Review and Adjudication Board of the State Administration for Industry and Commerce of China, Supreme People's Court, Zui Gao Fa Xing Zai No 26 (2018). See the No 114 GC at $<$ http:// www. court. gov. cn/ fabu- xiangqing- 216761. html> accessed 15 March 2021. For a review on the whole case, see Tian Lu, 'Chinese Supreme Court Rules in Favour of Dior, Attaching Great Relevance to
The layout of each of the top 10 IP cases consists of two sections. The first is the descriptive 'Case Briefing', which is followed by a few hundred words summarizing its 'Typical Significance'. This brief section can hardly provide substantial and in-depth analysis. Whereas the GC attempts to answer how a specific point should be tried, the 10 top IP cases seem to focus more on demonstrating each case's significance.

For example, one of the top 10 IP cases in 2019, namely VALEO SYSTEMES D'ESSUYAGE $v$ Xiamen Lukasi Automobile Parts Co, Ltd et al, ${ }^{19}$ was the first case heard by the newly established IP tribunal of the SPC (IPT SPC). This circumstance was noted at the beginning of the 'Typical Significance' section as follows:

[This case] was the 'first gavel' of the IPT SPC and marked the smooth launch of the unified appeal mechanism for technical cases and the first demonstration of the judicial functions of the IPT SPC. ${ }^{20}$

After this, the 'Typical Significance' section commented on the original ruling in a few sentences and stressed the case's notable aspects. For instance, the ruling helps clarify misunderstanding in judicial practice and provides guidance for improving judicial protection and reducing the cost of (patent) rights protection.

The IPT SPC began performing its statutory duties on 1 January 2019, which was undoubtedly a landmark event in terms of unifying the standards for the adjudication of IP cases. Notably, the incorporation of this event into the appraisal of a specific case, despite the overall legal climate, demonstrated that the SPC had adopted a broader view as it combined single cases in line with the broader social context. The IPMCs are not exclusive to the technical aspects of trials; a considerable portion of them involves demonstrating the courts' achievements. This is exhibited through the relevant announcements made by the SPC 'to showcase the achievements of the judicial protection of intellectual property rights by the people's courts. ${ }^{21}$

The publication style of the 50 IPMCs is even simpler than that of the top 10 IP cases. Only case names and reference numbers are listed, with no further explanations or comments. This style may be interpreted as lacking a specific, practical guiding point.

Due Process Interests of International Trade Mark Applicants' (2018) Journal of Intellectual Property Law \& Practice 13, 849- 851.

19 VALEO SYSTEMES D'ESSUYAGE v Xiamen Lukasi Automobile Parts Co, Ltd et al, Supreme People's Court (2019) Zhi Min Zhong No 2.

20 See < http:// www. court. gov. cn/ zixun- xiangqing- 226511. html> accessed 15 March 2021.

21 See eg < http:// www. court. gov. cn/ zixun- xiangqing- 153252. html> accessed 15 March 2021 
However, this approach returns the focus to the cases' complete original judgments rather than to selected content, thereby guiding the reader to investigate the case in a much more thorough fashion. Furthermore, the mere mention of a case reference is a sufficient incentive for the lower courts; earning SPC IPMC status is an honour and can be a criterion for evaluating the performance of courts and judges.

\section{IPMC from the SPC annual report}

Since 2009, the SPC has regularly issued the 'Annual Report on IP Cases' (hereinafter 'ARs').

Each AR's full text amounts to approximately 70,000 words, and their collections are published in print by China Legal Publishing House. Conveniently, a summary of each AR is available online on the SPC's website and provides an overview of IP cases heard nationwide, the cases' characteristics, and the highlighted IPMCs.

\section{IPT SPC IPMCs}

Since its establishment in 2019, the IPT SPC has been noticeably proactive in case-related analysis and in guidance work beyond the routine. The IPT SPC's Annual Report 2019 provided a detailed analysis of the characteristics of several critical types of IP cases, such as technology-related and jurisdiction-related cases. ${ }^{22}$ The IPT SPC selected 36 typical cases it tried in 2019 and summarized 40 adjudication rules accordingly published in the 'Summary of the Adjudication Gist (2019)'. ${ }^{23}$ In December 2020, on its second anniversary, the IPT SPC announced seven IPMCs with explicit comments and explanations. ${ }^{24}$

Similar IPMCs will be announced in the future, and the IPT SPC will become a regular, reliable, and stable source of example cases.

\section{E. IPMCs by the higher people's courts}

The higher people's courts can also issue IPMCs. Additionally, they release directive cases (参考性案例) and referential cases (参阅性案例) ${ }^{25}$; all three case types share the goal of guiding the trial work of local people's courts at all levels and guiding special people's courts within their respective jurisdictions. ${ }^{26}$ However, their geographic scope is local and thus much narrower than that of the SPC's GCs and IPMCs.

\section{F. IPMCs by IP Courts}

Throughout 2014, the establishment of three specialized IP courts in Beijing, Guangzhou, and Shanghai-all of which are intermediate people's courts-marked a new chapter for IP protection in China.

The IP courts are active in work related to example cases. They publish various cases, such as IPMCs with Summary and Typical Significance sections of the cases provided, and thematic case collections (eg the Beijing IP Court MCs on short video copyright). ${ }^{27}$

Having jurisdiction over the most diverse IP cases of the three IP courts, the Beijing IP Court is particularly diligent in publishing case interpretations. The case bulletin page on the court's website deserves special attention; this is where it publishes cases and comments monthly-sometimes weekly-using more plain and readable language than that found in official judgments. $^{28}$

On 24 April 2015, the Beijing IP Court was appointed by the SPC to be the first national IP case research base. Piloting an IP CGS was labelled an essential task. Therefore, the Beijing IP Court conducted a series of explorations. ${ }^{29}$ For instance, the mechanism of generating example cases was enriched; experts were chosen by the Beijing IP Court to select suitable example cases. Judges were encouraged to make judgements that will create example cases to achieve a cycle of examples. ${ }^{30}$

Parties and agents could submit 'complete and accurate effective judgements' obtained from public channels, such as China Judgements Online, to support their arguments. ${ }^{31}$ This process is now a common practice.

Furthermore, the Beijing IP Court has established an 'up-down, before-after, left-right' ('上下, 前后, 左
22 See < http:// www. court. gov. cn/ zixun- xiangqing- 225861. html > accessed 15 March 2021.

23 See < http:// www. court. gov. cn/ zixun- xiangqing- 225831. html> accessed 15 March 2021.

24 See < https:// mp. weixin. qq. com/s/ LMgGARxsT3fhQNXSbI56jw> accessed 15 March 2021.

25 See eg < http:// www. bjcourt. gov. cn/ zdal/ index. htm?c=100015003> accessed 15 March 2021.

26 art 9(1) of the Notice of the Supreme People's Court on Issuing the Several Opinions on Regulating the Trial Work Relations between the People's Courts at Different Levels, Fafa [2010] No 61, effective from 28 December 2010.
27 See <http:// bjzcfy. chinacourt. gov. cn/ article/ detail/ 2020/ 08/ id/ 5421652. shtml $>$ accessed 15 March 2021.

28 See $<$ http:// bjzcfy. chinacourt. gov. cn/ article/ index/ id/ M7Q0NDAwNjAwMiACAAA. shtml> accessed 15 March 2021.

29 See <http:// www. court. gov. cn/ zixun- xiangqing- 14266. html> accessed 15 March 2021.

30 See < http:// www. court. gov. cn/ fabu- xiangqing- 85572. html> accessed 15 March 2021.

31 For an introduction of the China Judicial Online, see Tian Lu, 'China Judicial Adjudicative Documents Website with more than 100 Million Records' (IPKat 29 September 2020) see < https:// ipkitten. blogspot. $\mathrm{com} / 2020 / 09 /$ china- judicial- adjudicative- documents. html $>$ accessed 15 March 2021. 
右') system concerning the order of reference. ${ }^{32}$ It means that when a case is tried, the legally effective judgments or orders made by the SPC or the Beijing Higher People's Court have a binding force in terms of the institutional authority of the Beijing IP Court (ie 'up and down' in terms of judicial hierarchy). The previous effective judgments made by the Beijing IP Court itself are also considered ('before and after'). References can also be made from the effective judgments of highquality theoretical reasoning by other courts ('left and right').

The 'up-down, before-after, left-right' approach may seem risky, for it significantly expands the scope of example judgments. ${ }^{33}$

\section{Critical remarks}

The aforementioned online accessible CGS has two glaring shortcomings. ${ }^{34}$

First, confusion regarding terminology is common and caused by the absence of necessary restrictions. The terms 'model case', 'typical case' and 'top case' are currently freely used by various agents, including courts, government departments and business entities such as media enterprises and law firms. ${ }^{35}$ This widespread use has led to a lack of unified formatting and definite selection criteria.

Secondly, some GCs provide brief rather than substantial content and lack explicit reference points. Therefore, some judges regard GCs as 'a mere formality that provides no significant help or convenience for trial practice'. ${ }^{36}$

GCs have those shortcomings partly because the CGS may be used only as a side reference in scenarios in which statutory laws do not provide a clear answer. China's CGS is fundamentally distinguished from that of the Anglo-American precedential case system, notwithstanding certain functional overlaps. Apart from the CGS, other rich reference sources are available for judges to evaluate and select. Moreover, recording which cases were ruled by considering GCs would be

32 Jing Yang, 'Practical Exploration of the Case Guidance System in the Field of Intellectual Property' (People's Court Daily 26 July 2017) $<$ http:// www. rmfyb. com/ paper/ html/ 2017-07/ 26/ content_ 128204. htm?div $=-1>$ accessed 15 March 2021.

33 Huali Chen, 'Discussion on the Core Disputes in the Intellectual Property Case Guidance System with Chinese Characteristics' (2018) 8 Intellectual Property 15-23.

34 For more of the CGS published in print, see Susan Finder, 'China's Evolving Case Law System in Practice' (2016) Tsinghua China Law Review 245, 259.

35 For instance, by the China National Intellectual Property Administration: The First Batch of Intellectual Property Administrative Enforcement Guiding Cases in December 2020, see < http:// www. gov. cn/ zhengce/ practically impossible when such considerations are made implicitly and are not made explicit in the judgments. In addition, judges in China sometimes do not write lengthy rulings unless they consider the case exceptionally important. ${ }^{37}$ Finally, within the CGS, only GCs are explicitly allowed to be referenced in similar subsequent cases; no such definite status has been conferred to other example cases (eg the IPMCs).

As novel reference guides, GCs represent the SPC's attempt to develop an indirect tool that guides lower courts' judicial activities. This is particularly evident where judges' discretion or creativity is required to provide a supplementary explanation to ambiguous statutory laws to ensure their uniform application.

Currently, the CGS is still an imperfect mechanism that remains in its early stages and produces numerous example cases. Many questions remain unsolved regarding aspects, including the possible withdrawal mechanism, clarification of 'binding force', and possible further hierarchical division regarding the guiding effects. The development of a well-defined CGS with more precise rules and structure still has much room for improvement.

However, the progressiveness of the CGS is undeniable. Its merits lie not in implanting a common law precedent system but rather in adding a multifunctional example case layer to existing judgments. This layer contributes to improvement in judicial officials' work quality and brings the public closer to law and practice, ultimately enhancing awareness of the law. The transparency is of remarkable value; because the original judgments and the courts' additional comments are published, observation, commentary, and participation are possible.

Although the CGS covers a small portion of the large volume of cases tried in China, cases incorporated in the CGS-particularly those selected by the SPC, the higher people's courts and the specialized courts like the IP courts-are all noteworthy for their features. Cases that repeatedly appear in various lists are undoubtedly key. For instance, the aforementioned

zhengceku/ 2020-12/ 16/5569961/ files/

12fcbb77641745079462b57b367af650. pdf $>$, The Typical Cases of Trade Mark Review in 2019, see <http:// ip. people. com. cn/ n1/ 2020/ 0427/ c136655-31690213. html > both accessed 15 March 2021.

36 Weijiang Pan, 'On the Effectiveness of Guiding Cases' (2016) 1 Tsinghua China Law Review 20-37.

37 Seminar Summary: On Building China's New IP Case System: A Discussion with Chinese Judges as well as Legal and Big Data Experts, Stanford Law School China Guiding Cases Project, Guiding Cases Seminars ${ }^{\mathrm{TM}}$, <https:// cgc. law. stanford. edu/ wp- content/ uploads/ sites/ 2/ 2017/ 09/ CGCP- English- Guiding- Cases- Seminar- 20171019. pdf $>$ accessed 15 March 2021. 
VALEO SYSTEMES D'ESSUYAGE v Xiamen Lukasi Automobile Parts Co, Ltd et al case was an SPC Gazette case, a top 10 SPC IP case, and a top 10 Shanghai Court Judicial Protection of IP Rights case in 2019.

Furthermore, the CGS's low level of availability, as argued by judges, does not hinder some of the unique advantages of the CGS from being beneficial in many areas outside the courtroom.

The simplified example cases are educational, easy to read, and accessible to the public. For judges, the CGS provides an incentive to generate high-quality judgments. The selection of a judge's ruling as an example case, particularly as a GC, is considered a career highlight for that judge. Such selection may also be an incentive for practitioners.

As for IP professionals, the platforms mentioned in this article are recommended sources for obtaining updated information on China's IP cases. Meanwhile, statutory laws and complete written judgments are irreplaceable in this country. Delving into the full context of the relevant original judgments and studying the facts and laws involved integrally, instead of cursorily consulting the summarized version that the CGS provides, remains essential. 